\title{
The Authenticity of Death: A Study of Tillich Existentialism in Lyudmila Ulitskaya's The Funeral Party
}

\author{
$1^{\text {st }}$ Rekha Nur Alisha \\ Russian Studies, Faculty of Humanities \\ Universitas Indonesia \\ Depok, Indonesia \\ rekha.nur@ui.ac.id
}

\author{
$2^{\text {nd }}$ Thera Widyastuti* \\ Literature Department, Faculty of \\ Humanities \\ Universitas Indonesia \\ Depok, Indonesia \\ thera.widyastuti@gmail.com
}

\begin{abstract}
While the majority of people regard death as a frightening event, human beings evince a remarkable variety in the ways in which they confront and tackle death. Human reactions to death can range from being terrified to welcoming. This article explores how the protagonist in Lyudmila Ulitskaya's novel, The Funeral Party, handles his being when he is diagnosed with an unidentified sickness and is faced with the prospect of premature death. The present study attempts to elucidate the protagonist's endeavor to achieve authenticity despite his impending death. To this end, this paper scrutinizes the text for his actions and choices on the basis of Tillich's [1] existentialism. The article hypothesizes that Alik achieves authenticity in his handling and confrontation of his death. The data for the analysis are compiled via a study of the extant literature. A descriptive qualitative analysis is performed on the obtained data. The findings of this study validate the hypothesis and reveal that the protagonist does attain his desired authenticity through three significant actions: taking charge of his own choices, fully participating as a member of his society, and demonstrating acceptance by being grateful for his illness.
\end{abstract}

Keywords-existentialism, death, Russian literature, Tillich, Ulickaja

\section{Introduction}

Human beings have historically considered death to be a terrifying eventuality, perhaps because of its complete uncertainty. The very manifestation of death is simultaneously certain and uncertain. It is impossible to know when a certain person will die, on what date, at what time, at what place, and how. However, this lack of awareness is also conjoined with the absolute certainty of the event. Regardless of the uncertainty of how and when death will happen, there lies the certainty that death will surely happen. This feature has always made death the final, the most enigmatic, and the most fearful occurrence of human existence. Lamar H. Watkins cites Heidegger [2] as saying that death is the only one certainty for all humans.

In addition to being attached to the concepts of certainty and uncertainty, death is often associated with the concept of loss. The person who dies loses the ability to directly connect with living acquaintances. Meanwhile, those who continue living lose a fellow human being with whom they may have been emotionally connected. Death takes away the human ability to connect with one's environment.

Human beings respond to impending death with discrete emotions and actions: some feel and display fear and resentment as if they are forced to encounter an old enemy who aims to attack them; others may confront the prospect of dying with acceptance and peace as if welcoming a dear old friend. Heidegger [3] provides two scenarios in this context: first, a person may disregard the inevitability of death and may also neglect the notion that the state of being will return to a state of nonbeing; second, an individual may recognize that death is inexorable and welcome it.

The protagonist of Lyudmila Ulitskaya's 1997 novel Веселье Похороны/The Funeral Party [4] is called Alik, a Russian immigrant living in an apartment in Manhattan, New York. Alik suffers from an unidentified illness that renders him completely immobile: he can only lie in bed. Ulitskaya, taking Alik's misfortune into account, depicts him as someone unique who is not afraid of death and who views his imminent death as a certainty.

Ulitskaya's treatment of death in this novel is distinctive: she blends the two opposing scenarios. This integration of the two conflicting concepts is simply yet explicitly articulated in the very title of the novel: Веселье may be translated into English as "cheerful" and Похороны as "funeral." Веселье is associated with happiness, while Похороны is associated with grief and loss. Deconstructed into grammatical functions, Похоронь is a noun and Веселье is an adjective. Adjectives function to define and explicate nouns. Ulitskaya's choice in pairing the defining adjective Веселье with the noun Похоронь thus allows the latter term's mournful and sorrowful connotations to transform into an optimistic and unfrightening Phenomenon. As the title of the novel, the phrase Веселье Похороны itself speaks to the protagonist's perspective on death. Despite the pain that racks Alik's body, he assents to his certain death with peace and grace. Alik's coping with his illness takes on the tone of a "party" or celebration. This atmosphere of festivity is evidenced by Alik's decision to spend the rest of his life with the people who live with him, in a vibrant and celebratory acknowledgment of his forthcoming death.

Lyudmila Ulitskaya is a contemporary Russian writer of Russian-Jewish descent. She was born on February 21, 1943, to highly educated parents who resided in a city called Davlekanovo in Bashkiria. She earned her degree in biology from Moscow State University, specializing in genetics and biochemicals. Subsequently, Ulitskaya worked at a genetic institute. However, in 1979, Ulitskaya's research license was 
revoked as punishment for translating a novel that was then banned by the Russian government.

Ulitskaya revealed in a May 2003 [5] interview with Marina Georgadze that her mother once worked as a biochemist at a medical institution, but was later dismissed from her job. A persistent sense of fear and the threat of looming danger overshadowed the lives of Ulitskaya and her family after her mother was discharged. Ulitskaya elucidated that a constant fear accompanied her as a child and shaped her into an adult who felt little to no anxieties in life. Ulitskaya thinks of trepidation as something that must be faced and her own attitude toward fear is reflected in the manner in which Alik handles death in Веселье Похороны/ The Funeral Party.

Further, Ulitskaya's Jewish background also influenced her attitude to death in this particular novel. Jewish scriptures state that life is valuable and Jewish law prohibits any act that accelerates death. They also prohibit the adoption of any actions that may prevent pain or suffering when human beings are faced with death. Euthanasia, suicide, and assisted suicide are all strictly forbidden by Jewish religious tenets. The Talmud even restricts minor acts such as moving a suffering person's arm if that act can potentially accelerate an individual's death. However, Jewish law allows the medical discharge of patients whose lives are artificially prolonged. Jewish religious laws view death as a natural occurrence that should neither be accelerated nor postponed. These beliefs about death are congruent with Alik's general attitude throughout the novel.

The focal research question examined by this paper pertains to the way in which the protagonist handles his being once he is diagnosed with an unidentified illness and has to face premature death. The paper attempts to uncover the protagonist's approach to the attainment of authenticity despite his impending death. To this end, it conducts a textual scrutiny of Alik's actions and choices using Tillich's existentialism [1] as the yardstick for its evaluation. The paper hypothesizes that Alik achieves authenticity in dealing with and in facing death, and the significance of this research endeavor vests in its exploration of existential values displayed in literary works, specifically in Russian contemporary literature. The major findings of this study primarily concern the main character's existential approach toward death and the reported insights contribute to the larger field of literary studies through the depiction of existentialism and existential values in Веселье Похороны/The Funeral Party.

The theme of literary expositions of existentialism has been probed by previous researchers. Three notable pieces of such research are discussed here. First, Thera Widyastuti [6] discusses "The Concept of Death in Accordance with Existentialism in Leo Tolstoy's Smert' Ivana Illicha (1995)." This paper explores human existence through the concept of death by analyzing Ivan Illich, the novella's protagonist. Widyastuti's [6] study reveals that Ivan fears death and is afraid of facing death despite his elevated (Russian aristocrat) social class, high level of education, and successful career. Gerasim, the deuteragonist of the narrative, is poised in sharp contrast to Ivan. He is Ivan's servant, is younger than his master, and hails from an underprivileged (proletariat) social class. Nonetheless, his perspective of death is much more mature. Gerasim is not afraid of death and, in fact, regards death as a natural inevitability. Moreover, Widyastuti [6] also describes Tolstoy's distinct writing style that appears to defend the lower social classes of society in Smert' Ivana Illicha/ The Death of Ivan Illyich. The particular quality of Tolstoy's prose is demonstrated in the way he constructs his characters and their personalities. Tolstoy uses Gerasim as a symbol of the lower social classes who, despite their socio-economic limitations, prove more progressive and mature in their apprehension of human existence and death. Gerasim offsets Ivan, who represents the higher social classes and their myriad privileges. Ultimately, the reader realizes that Gerasim commands a superior understanding of human existence.

The second study that deserves mention is Dennis Drummond's [7] "Existentialist Values in Debra Daley's 'The Strange Letter Z'" (1998), a paper that explores existentialist values, specifically as evinced by Sartre and Camus, in Debra Daley's novel, The Strange Letter Z. Drummond analyzed existentialist values through the actions of the characters in the text, referencing the conceptual construct of existentialism as expounded in the work of Sartre and Camus. Drummond's [7] analysis discloses that the characters of The Strange Letter $Z$ are stuck in what Sartre calls mauvaise foi (bad faith) (1970: 28-29). The characters do not live or enjoy their life; instead, they merely exist in expected daily routines and socially-approved behavioral patterns, dutifully following the diktats of their society. However, two main characters Nerida and Alexis manage to escape this mauvaise foi because they perform what Camus calls the double verite $d u$ corps et de l'instant (double truth of the body and the moment) (1950: 86).

Third, John A. Dern's [8] study, "Sin Without God': Existentialism and 'The Trial"' (2004), analyzes Camus' exposition of existentialism in Franz Kafka's The Trial (1925) and the novel's film adaptation by Orson Welles. Dern's [8] analysis demonstrates that Kafka's Joseph K. almost succeeds in achieving the affirmation of his existence in terms of Camus' theory; however, Welles' version of Joseph K. fails to attain the same state. According to Dern, Kafka's Joseph K. is able to accept the absurdity of his life; Welles' Joseph K. fails in this respect.

\section{Method}

The present article uses a qualitative approach and conducts a descriptive textual analysis. Sugiono [9] states that the method of descriptive analysis presents and explains a conceptual position vis-à-vis the research object through the examination of collected data. The present study uses a study of the extant literature as its data collection technique. According to Nazir [10], a literature study is a technique of compiling data through the appraisal of varied relevant texts such as books, journal articles, notes, or reports relating to the research topic.

The $e$-pub version of Lyudmila Ulitskaya's novel Веселье Похороны/The Funeral Party published by Eksmo-Press in Moscow in 2004 [4] forms the research corpus for the present paper. It was downloaded from http://flibusta.is/b/61898 on March 12th, 2019. The supporting literature for this article encompasses two books: 
John Macquarrie and Edward Robinson's translation of Being and Time by Martin Heidegger [3] published in 2001 by Blackwell Publishers, Oxford; and Paul Tillich's The Courage to $B e$ published by The University Press in Aberdeen in 1952 [1].

\section{Results and Discussion}

The plot of Веселье Похороны/The Funeral Party is articulated through a mixed narrative structure of flashbacks and flashforwards. Readers are explicitly informed in the early chapters through a statement attributed to Alik that he understands and accepts his existence as a human who is both being and nonbeing.

\section{“- Придется сказать тебе одну вещь.}

Правая рука его висела вдоль тела как неживая. Левой он прижал Иринину густо русую голову, волосок к волоску причесанную, с черным шелковым бантом в натуральных жемчужинах по краю, $u$ шепнул ей в ухо:

— Ирка, я скоро помру.” (2-3) [4]

'I've got to tell you something." he said.

His right hand hung lifelessly by his body. With his left hand he touched her thick, light brown hair, each strand kept in place by a black silk bow edged with real pearls, and whispered in her ear:

"Irka, I'm dying."” (3) [11]

Ирка, я скоро помру becomes a key phrase, telling readers that Alik comprehends the reality of his condition and that his existence as a human now incorporates both being and nonbeing. He is also willing to invite other beings into the discourse about his impending death. He welcomes the participation of another person in the acknowledgment that he is dying. Alik's existence does not dissolve because he is faced with death; on the contrary, he accepts and embraces his dying as an aspect of his existence. Similarly, Alik does not hesitate to mark himself as the subject of his death. He uses $я(j a)$ or "I" in English as the word to represent himself.

Вот уже две недели, как он был дома. Сказал врачам, что не хочет умирать в больнице. Были и ещзепричины, о которых они не знали и знать не должны были." (1) [4]

'This was his second week at home. He had told the doctors at the hospital that he didn't want to die there. There were other reasons for this which they didn't know, and which he didn't tell them.'

As the first chapter of the story continues, readers come to understand that Alik can successfully practice Tillich's [1] first tenet, "the courage to be as oneself." Alik achieves this mettle by making decisions for himself: despite his debilitating condition, he decides that he does not want to be hospitalized.

The phrase “...не хочет умирать в больнице” accords readers with two significant pieces of information. First, it explicitly tells readers that Alik does not want to die in the hospital; it also implicitly suggests that Alik chooses to die in another venue. Alik realizes that he is unable to control how and when he will die, but he is equally aware that he can select the place where he will die, and that it will not be in a hospital. Second, this phrase demonstrates Alik's awareness of his forthcoming death. Alik emerges as the subject once again and takes charge of the things that he can control.

As the plot progresses, Alik proves that he can apply Tillich's [1] second principle, "the courage to be as a part." He decides to not be hospitalized and instead, he chooses to be taken care of at his apartment. This decision affords Alik the opportunity to interact more with and participate in the lives of his circle of loved ones or his community of people.

The storytelling technique of multiple flashbacks and flashforwards adds an essential aspect to the present study. This back and forth narrative style demonstrates the process of Alik's attainment of his ability to apply "the courage to be as a part." Readers come to know through the flashbacks and flashforwards that Alik had already begun to put this particular concept into practice when he was still in Moscow and other parts of the world and much before he settled down in his apartment in New York. At the beginning of the novel, readers are told that Alik lives at an apartment in Manhattan along with several other Russian immigrants. In the middle of the narrative, Ulitskaya invites the readers to delve into Alik's past, a time when he was still healthy and able-bodied. The old Alik, readers learn, moved from one place to another, and engaged intimately with the community in every city that he visited. By the time the novel reaches its end, readers are aware from multiple sections of the narrative that Alik's past acquaintances had all came by to offer their condolences: they had all attended Alik's funeral party.

"Народ шел и шел. Многие не знали о его смерти, забегали просто так. Знакомых у него было очень много и помимо тех, кто составлял русскоеврейскую колонию этого огромного города. Пришел какой-то итальянский певеи, с которым Алик подружился когда-то в Риме. Пришел хозяин кафе и действительно принес чек." (66) [4]

'People kept coming. Some didn't know he had died, and had just come over to visit. A number of his friends arrived, including several from outside the city's Russian-Jewish community. There was an Italian singer, one of Alik's friends from Rome, and the owner of the cafe opposite, who brought Nina a cheque as he had promised.' (77) [11]

The sentence "Звонил телефон то из Парижа, то из Ярославля." is a strong iteration of Alik's charisma: he is able to motivate other beings to visit him. The "visits" occur both through direct and indirect communication (through telephone calls). Alik's existence, in fact, is uniquely able to unite other beings even when he is not alive.

The integrity of Alik's existence is thus consistently achieved through the entire novel, and to its end. Alik is, therefore, able to observe Tillich's [1] third and final principle, "the courage to be" which can also be read as "the courage to accept acceptance." The second chapter tells readers that Alik had given Maika a video cassette that she was to play when he had died and his body no longer existed.

“Она стянула шорты. Через ткань ощутила прямоугольную коробочку. Свернула все аккуратно, 
чтобы не выпало. Инструкицю она помнила наизусть. Сегодняшнюю ночь она провела возле Алика. Не всю, несколько часов. Нинка вырубилась и спала в мастерской, а Алик не спал. Он попросил ее, $u$ она все сделала, как он хотел, и теперь эта коробочка была доказательством того, что именно она и есть его самый близкий человек." (7) [4]

'As she stepped out of her shorts she felt the small rectangular box through the material. She wrapped everything up carefully, to make sure nothing fell out. She remembered every word of her instructions. She had spent last night beside Alik, not the whole night, just a few hours. Nina had gone off to sleep in the studio, but Alik hadn't sleep; he had called for her, she had agreed to do everything he had asked, and now, that little box was proof that she really was the one who was closest to him.' (8) [11]

The videocassette is not mentioned again until the end of the novel. It is not until chapter twenty that the videocassette is played in Alik's apartment on the day of his funeral party.

- Послушайте все! - крикнула Тишорт. Ирина замерла - чего угодно она могла ожидать от своей странной девочки, но только не публичного выступления.

- Послушайте! Алик просил вам вот что передать! Все обернулись в ее сторону - она багровела на глазах, как индикаторная бумага при химической реакции, но тут же села на корточки и вставила кассету в магнитофон, который, как обычно, стоял на полу. И почти сразу же, почти без паузы, раздался ясный и довольно высокий голос Алика:

— Ребятки! Девчушки! Зайки мои! (73-74) [4]

- Listen everyone! — Maika broke in. Irina froze: she could expect anything from her strange little girl, but not a speech.

- Listen everyone! Alik asked me to give you this! Everyone turned to look at her; her face was crimson, like reagent paper during a chemical reaction. Next minute she squatted on her heels and pushed a tape into the cassette-player which stood on the floor. Almost immediately, without a pause, Alik's clear, high voice rang out: "Boys and girls! My Pussy-cats and Cuckoos!" (83) [11]

Readers receive two pieces of information this action instigated by Alik. First, the act indicates that Alik had prepared for his death and thought deeply about the words he would say to the people he would leave behind. This mindfulness demonstrates that Alik does not only accept his death; he also makes arrangements for the eventuality. Second, Alik transcends the constrictions of his human condition of both being and nonbeing through this simple and practical act of using the videocassette as his final medium of interaction. In choosing this method, Alik continues to exist even though he is dead and is also able to connect with his circle, albeit only through a one-way (indirect) means of communication. Moreover, Alik can also express his gratitude toward his unidentified illness.

Я даже благодарен этой проклятой болячке. Если бы не она, я бы не знал, какие вы... Глупость сказал. Всегда знал." (75) [4]

'I'm even grateful for my damned illness. If it wasn't for this I'd never have known how good you are.'

(84) [11]

Readers gain two insights from the above passage. First, they once more receive a direct statement from Alik speaking as $я(j a)$ "I," symbolizing Alik's positioning of himself as the subject in charge. Alik uses $r(\mathrm{ja})$ "I" at the beginning of his sentence when he expresses his gratitude. The use and the placement of the word "I" take the focal position of signification in existentialism. The Russian language also allows its speakers to retain or remove the subject of a verb from their iterations. It also offers a variety of options for its users. For instance, a person choosing to utter the subject of a verb can also select its placement before or after the verb: in the beginning, at the middle, or at the end of a sentence. Therefore, the choice and the positioning of the word $x(j a)$ "I" demands deliberation and delivers critical information. It is congruent with Alik's achievement of authenticity in his existence. Alik presents himself first as the subject in charge, then he states the verb благодарен (blagodaren) which conveys his gratitude.

Second, the content of Alik's sentence is noteworthy. Alik states that he is grateful for his illness. The word проклятой/damned is also the adjective Ulitskaya uses to describe Alik's illness. It demonstrates Alik's experience of acute suffering because of his illness. However, Alik finds love and compassion despite his suffering, both within himself and from his circle of love. Alik's gratitude is thus extended not just to his disease, but also to his community (society) that stands with him even after he ceases to exist. Alik accepts his condition in agreement with Tillich's principle of "the courage to accept acceptance" and also accepts his social environment with the same wholehearted integrity. Further, he is able to articulate his acceptance by actively, explicitly, and verbally expressing his appreciation.

\section{Conclusions}

The above examination demonstrates that the novel's protagonist Alik achieves authenticity in full accordance with Tillich's understanding of existentialism [1] through three important actions observed in the text. First, he takes charge of his own choices. Second, he participates wholeheartedly as a member of his society. Third, he demonstrates his acceptance by acting to expressly articulate his gratitude for his illness. Alik accepts and comprehends his condition as a human who is both being and nonbeing. He also does not hesitate to invite other beings into his discourse of acknowledgment of his illness and expected death. Throughout the novel, narrated through the technique of multiple flashbacks and flashforwards, the protagonist is shown as able to achieve authenticity and also capable of consistently applying the tenets of existentialism. Ulitskaya presents readers with many versions of Alik; despite the many facets, his existence remains unswervingly authentic: he is always the subject in charge with the courage to be. 


\section{References}

[1] Tillich, Paul. (1952). The Courage to Be. Aberdeen: The University Press.

[2] Watkins, Lamar H. (1968). Paul Tillich's analysis of the existential condition of man and its implications for social casework theory and practice. Atlanta University, Atlanta, United States of America.

[3] Heidegger, Martin. (2001). Being and Time. (John Macquarrie \& Edward Robinson, Trans.). Oxford: Blackwell Publishers.

[4] Ulitskaya, Lyudmila. (2004). Веселье Похороны (The Funeral Party). Moskow: Eksmo-Press.

[5] Georgadze, Marina. (n.d.). Персона Недели: Людмила Улицкая (Person of the Week: Lyudmila Ulitskaya). НаСтоящая Jumepamypa (Real Literature). Retrieved from https://web.archive.org/web/20040815010253/http://www.litwomen.r u/autogr3.html

[6] Widyastuti, Thera. (1995). Konsep Kematian menurut Eksistensialisme dalam Smert' Ivana Illicha karya Leo Tolstoy (The concept of Death according to Existentialism in Smert 'Ivana Illicha by Leo Tolstoy). Thesis. Universitas Indonesia, Depok, Indonesia.

[7] Drummond, Dennis. (1998). Existentialist Values in Debra Daley's "The Strange Letter Z". Journal of New Zealand Literature (JNZL), $16,115-132$.
[8] Dern, A. John. (2004). "Sin without God": Existentialism and "The Trial". Interdisciplinary Literary Studies, 5, 94-109.

[9] Sugiono. (2009). Metode Penelitian Kuantitatif, Kualitatif, dan R\&D (Quantitative, Qualitative, and $R \& D$ Research Methods). Bandung: Alfabeta.

[10] Nazir, Mohammad. (1988). Metode Penelitian (Research Methods). Jakarta: Ghalia Indonesia.

[11] . (2002). The Funeral Party. (Cathy Porter, Trans.). New York: Schocken Books.

[12] Baird, Robert M. (1976). Existentialism, Death, and Caring. Journal of Religion and Health, 15, 108-115.

[13] Barentsent, A. A. (1976). Russische Gramatika. Amsterdam: Universitet Van Amsterdam.

[14] Gessen, Masha. (2014, September 29). The Weight of Words. The New Yorker. Retrieved from https://www.newyorker.com/magazine/2014/10/06/weight words

[15] Rich, Tracey R. (n.d.). Life, Death, and Mourning. Judaism 101. Retrieved from http://www.jewfaq.org/death.htm\#Death

[16] Shariatinia, Zohreh. (2015). Heidegger's Ideas about Death. Pacific Science Review B: Humanities and Social Sciences, 1, 92-97. 